\title{
In vitro anticancer activity of acetylshikonin action against cervical cancer
}

\author{
Hui Sun, Hongying Xu, Aihua Zhang, Ping Wang, Ying Han, Xijun Wang*
}

\begin{abstract}
Cervical cancer is a malignant neoplasm and is the second commonest cancer in women worldwide. Despite the availability of various treatment modalities, the 5-year survival remains poor. Therefore, it is absolutely necessary to explore drugs capable of preventing and treating cervical cancer. Plant-derived natural products are widely used as adjunct to chemotherapy for this type of cancer. Our study aims to investigate the effects of acetylshikonin, an acetyl derivative, isolated from a Chinese medicinal herb Lithospermum erythrorhizon Sieb. et Zucc., a folk medicine with a long history of safe use for clinically treating cervical cancer in China. MTT assay was used to determine the in vitro anticancer effects of acetylshikonin on human cervical cancer Siha cells. The expression of caspase-3 and -8 proteins were determined. Flow cytometry and quantitative RT-PCR were performed to detect the expression level of Siha cells associated markers and regulatory genes. In Siha cell lines, acetylshikonin inhibited cell growth in a dose-dependent manner. The preferential expression of Siha cells related marker, regulatory genes were also highlighted. It arrested the cell cycle by blocking transition from $S$ phase to G2/M phase and induced apoptosis of Siha cell through activating caspase- 3 and caspase-8. In the current study, acetylshikonin can be taken as a promising natural lead for cervical cancer.
\end{abstract}

Keywords: Cervix cancer; Siha cell; acetylshikonin; natural products.

Received: 2 February 2014 / Accepted: 18 March 2014 / Published online: 1 April 2014

(C) Horizon e-Publishing Group

CITATION

Sun, H., Xu, H., Zhang, A., Wang, P., Han, Y., \& Wang, X. (2014). In vitro anticancer activity of acetylshikonin action against cervical cancer. Plant Science Today, 1(2), 39-45. http://dx.doi.org/10.14719/pst.2014.1.2.15

AUTHOR AFFILIATION

National TCM Key Laboratory of Serum Pharmacochemistry, Key Laboratory of Metabolomics and Chinmedomics, Department of Pharmaceutical Analysis, Heilongjiang University of Chinese Medicine, Heping Road 24, Harbin 150040, China

*CORRESPONDENCE: Prof. Xijun Wang, Tel. \& Fax +86-451-82110818 Email:xijunwangls@126.com; aihuaz@yeah.net

\section{Introduction}

Cervical cancer remains the leading cause of cancer death among females worldwide. It is estimated that there are 473,000 cases of cervical cancer, and 253,500 deaths per year (Chung \& Lambert, 2009; Kim et al., 2010). Cervical cancer is currently ranked as the second most common cause of cancer-related morbidity and the third most common cause of mortality worldwide (O'Keefe et al., 2009). Treatment of cervical cancer has typically been viewed as surgical with possible adjuvant therapy versus initial radiotherapy and platinum-based chemotherapy (Yue et al., 2008; Henares, Mizutani, Sekizawa \& Hisamoto, 2008; Kelly et al., 2010). But the combination treatment has significant risk of neutropenia, anemia, and thrombocytopenia side effects, also result in drug resistance. Clinical drug resistance to platinum-based chemotherapy is considered a major impediment in the treatment of cervical cancer (Dzoyem et al., 2012). Its current treatments have a number of undesired adverse side effects.

Chinese medicinal herb Lithospermum erythrorhizon Sieb. et Zucc. (Fig. 1A) is a folk medicine with a long history of safe use for clinically treating cervical cancer in China (Mu, Wei \& Liu, 2012; Zhang et al., 2012). Acetylshikonin (Fig. 1B), a naphthoquinone isolated from the Chinese herb, the dried purple roots of L. erythrorhizon Sieb. et Zucc., has been found to possess various biological activities, including antibacterial, antipyretic, anti-microbial, anti-fungal, anti- HIV, anti-inflammatory, anti-tumor and analgesic activity (Fang, Shao, Zhang \& Wang, 2005; Chung et al., 2005; Kim et al., 2007; Takai, Ueda, Nishida, Nasu \& Narahara, 2008). It demonstrated antitumor effects on human lung adenocarcinoma cell line A549, human hepatocellular carcinoma cell line Bel-7402, human breast adenocarcinoma cell line MCF-7 and mouse Lewis lung carcinoma cell line (Masuda et al., 2003; Singh, Gao \& Lebwohl, 2003; Staniforth, Wang, Shyur \& Yang, 2004), however the literature relating to cervical cancer Siha cells has not been found yet. Cancer is one of the major health problems worldwide and its current 
A

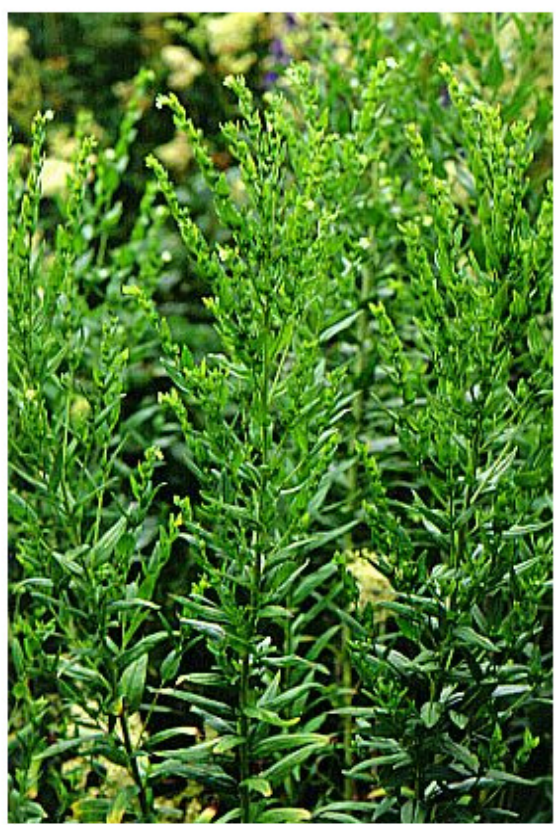

B<smiles>CC(=O)C(CC=C(C)C)C1=CC(=O)c2c(O)ccc(O)c2C1=O</smiles>

Fig. 1. Lithospermum erythrorhizon Sieb. et Zucc. (A) and the chemical structure of acetylshikonin (B)

treatments have a number of adverse side effects. Natural compounds may reduce these. Currently, a few plant products are being used to treat cancer. Therefore, in this study, Acetylshikonin, a natural naphthoquinone extracted from Lithospermum erythrorhizon, was undertaken to find out if acetylshikonin had any effects on proliferation, differentiation and apoptosis of cervical cancer Siha cells, and to investigate the possible mechanism on a molecular level.

\section{Materials and methods}

\section{Reagents and Materials}

Dulbecco's modified Eagle's medium (DMEM) was purchased from the HyClone Co., USA; foetal bovine serum (FBS) from Yuanhengshengma Biotechnology Co., Ltd. (Beijing, China); trypsin from the Gibco Co., USA (Gibco company, USA); and collagenase I and thiazolyl blue was was purchased Sigma Chemical Co., USA. Hank solution and $0.1 \mathrm{~mol} / \mathrm{L}$ phosphate buffer solution (PBS) were purchased from Cell Center of Peking Union Medical University. TRIzol reagent was purchased from Invitrogen Co., Ltd. Caspase-3 and -8 kit was purchased from Santa Cruz Biotechnology (CA, USA). MTT was obtained from Sigma Chemical (Sigma, USA). Acetylshikonin and hydroxycamptothecin were obtained from National Institute for the Control of Pharmaceutical and Biological Products (Beijing, P.R. China) and was confirmed by high-performance liquid chromatography. All other chemicals were obtained from Sigma (St. Louis, MO). Siha and Hela cell lines were obtained from Research Center of Harbin Medical University (Harbin, China). Cells were cultured in DMEM medium (Hyclone, USA) supplemented with 10\% heat-inactivated fetal bovine serum (FBS) (Yuanhengshengma, Beijing, China) at $37^{\circ} \mathrm{C}$ in a humidified $5 \% \mathrm{CO}_{2}$ atmosphere.

\section{Viability analysis}

The inhibitory effects of acetylshikonin and total naphthoquinones on cell line Siha and Hela were measured by microculture tetrazolium (MTT) assay. Cells were dispensed in 96-well microculture plates (Nunc, Denmark) at a density of $1 \times 105$ cells per well. After incubation for 24 hrs, cells were treated with different concentrations of the two sample drugs respectively, the concentrations were $0.025 \mu \mathrm{g} / \mathrm{ml}, 0.05 \mu \mathrm{g} / \mathrm{ml}, 0.25 \mu \mathrm{g} / \mathrm{ml}$ for acetylshikonin. The absorbance was detected by MTT assay at the indicated time points. Inhibition (\%) $=(1-$ ODMAT $/$ ODCG $)$ $\times 100 \%$.

\section{Morphological observation}

Siha cells were dispensed in a 6-well plate (Nunc, Denmark) at a density of $2 \times 105$ cells per well. After $24 \mathrm{hrs}$ cell culture, cells were treated with different concentrations of hydroxycamptothecin (HC), and acetylshikonin respectively for $24 \mathrm{hrs}$, the drug-treated cells were harvested by centrifugation, resuspended in the medium and dripped onto a glass slide. The cells on a glass slide were observed under light microscope (Olympus). 


\section{DNA fragmentation analysis}

Siha cells $(1 \times 106)$, were collected by centrifugation and resuspended in $100 \mu \mathrm{L}$ lysis buffer [ $1 \mathrm{mM}$ Tris- $\mathrm{HCl}(\mathrm{pH} 8.0)$, $0.5 \mathrm{mM}$ EDTA], incubated for $10 \mathrm{~min}$ at $4^{\circ} \mathrm{C}$. After centrifugation at $12000 \mathrm{rpm}$ for $2 \mathrm{~min}$, the fragmented DNA was recovered from supernatant. $20 \mathrm{~g} / \mathrm{L}$ RNase A was added to the supernatant and incubated for $1 \mathrm{hr}$ at

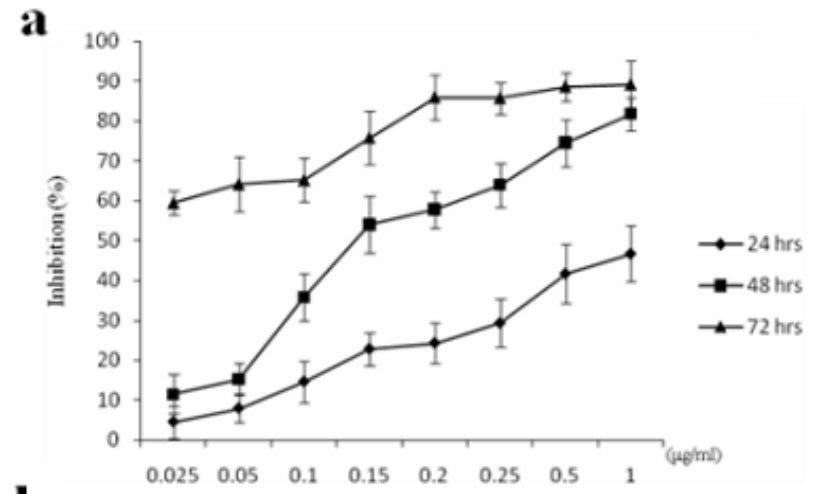

b
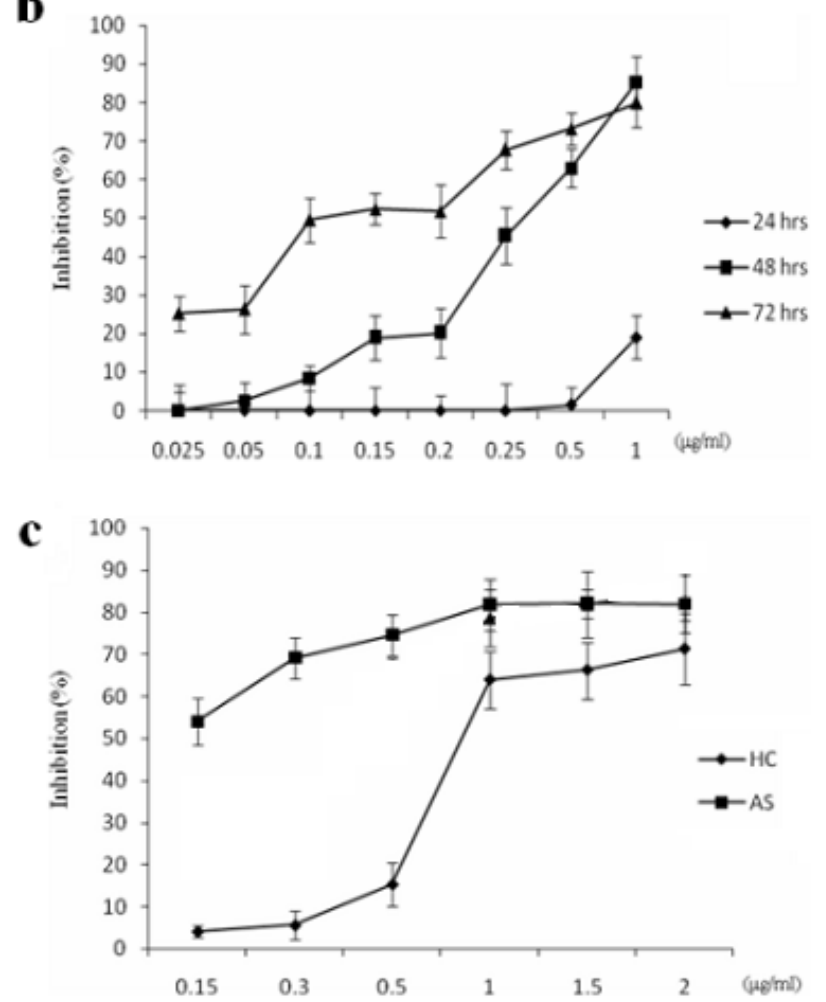

Fig. 2. Inhibitory effects of acetylshikonin on Siha and Hela cells. Cells were cultured with medium containing

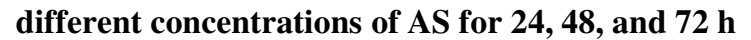
respectively and viability of cells was measured by MTT method. a: effect of AS on Siha cells; b: effect of AS on

Hela cells; c: Inhibitory effects of

hydroxycamptothecin, and acetylshikonin on Siha cells. Each value represents as mean \pm S.D. $(n=3)$. $37^{\circ} \mathrm{C}$, followed by $20 \mathrm{~g} / \mathrm{L}$ proteinase $\mathrm{K}$ for $1 \mathrm{hr}$ at $37^{\circ} \mathrm{C}$, finally by $0.5 \mathrm{M} \mathrm{NaCl}$ and $50 \%$ avantin for $24 \mathrm{hrs}$ at $-20^{\circ} \mathrm{C}$. The suspension was centrifuged at $12000 \mathrm{rpm}$ for $15 \mathrm{~min}$ and the supernatant was discarded. The pellet was dissolved in TE solution [10mM Tris- $\mathrm{HCl}(\mathrm{pH} 7.4), 1 \mathrm{mM}$ EDTA ( $\mathrm{pH}$ 8.0)] and fragmented DNA was detected by agarose gel electrophoresis.

\section{Lactate dehydrogenase activity}

Siha cells were dispensed in 24-well plate at a density of $1 \times 105$ cells per well. After 24 hrs cell culture, cells were treated with different concentrations of acetylshikonin for $24 \mathrm{hrs}$ and each well was added $1 \mu \mathrm{g} / \mathrm{ml}$ hydroxycamptothecin. The supernatant was collected and used for LDH activity analysis according to instruction of commercial kit (Boya Biotechnology Co, Shanghai, China).

\section{Caspase- 3 and caspase-8 activity analysis}

Siha cells were dispensed in 6-well plate at a density of $1 \times 105$ cells per well. After 24 hrs cell culture, cells were treated with different concentrations of acetylshikonin, and hydroxycamptothecin for $24 \mathrm{hrs}$. Cells were collected and washed with PBS and resuspended at a density of $1 \times 106$ cells in lysis buffer, then incubated on ice for 10 min. After centrifugation at $1200 \mathrm{rpm}$ for $5 \mathrm{~min}$, caspase-3 and caspase- 8 activity in the supernatant was determined according to instruction of commercial kit Santa Cruz Biotechnology (CA, USA).

Real-time reverse transcriptase polymerase chain reaction (RT-PCR) analysis

Total RNA was isolated from $1 \times 107$ cells that was pretreated with different concentrations of acetylshikonin and hydroxycamptothecin (HC) using TRIzol Reagent (Invitrogen, USA). After incubation with DNase I (Boya Biotechnology Co, Shanghai, China) and RNase inhibitor (Boya Biotechnology Co, Shanghai, China), $2 \mu \mathrm{g}$ total RNA was subjected to cDNA synthesis in a $20-\mu$ l reaction volume using ThermoSctipt TMRT-PCR System (Invitrogen Co, USA) with oligo (dT)20 primers. $2-\mu$ l cDNA aliquots was used as templates and amplified with the following thermal cycling conditions: denaturation at $94^{\circ} \mathrm{C}$ for $5 \mathrm{~min}$, followed by 35 cycles of $10 \mathrm{~s}$ at $94^{\circ} \mathrm{C}, 20 \mathrm{~s}$ at $60^{\circ} \mathrm{C}$ using Light-cycler II PCR (Roche co., USA). A 76 bp fragment of caspase-3 was amplified with primers 5'-ctggactgtggcattgagaca-3' and 5'-agtcggcctccactggtattt-3'. A $101 \mathrm{bp}$ fragment of actin was amplified with primers 5'-cccagcacaatgaagatcaagatcat-3' and 5'-atctgctggaaggtggacagcga-3'. The copy number was calculated and all the data were normalized to actin. Fluorescent signal was captured in the whole procedure to determine the amounts of PCR products. 

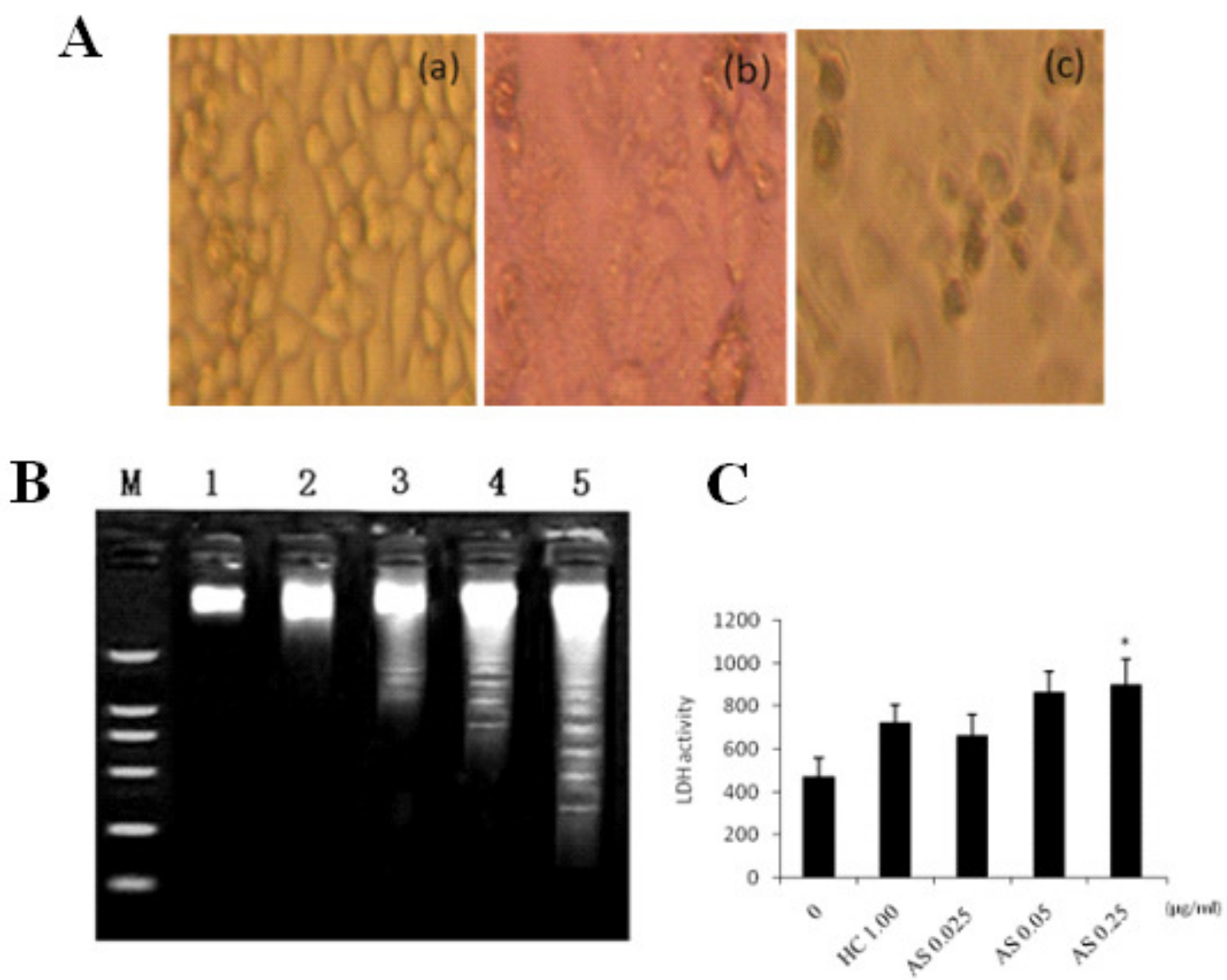

Fig. 3. Effect of AS on Siha cells. A. Morphological changes of Siha cells induced by AS. The morphological changes were observed under light microscope. a: $0 \mu \mathrm{g} / \mathrm{ml}$. b: $\mathrm{HC} 1 \mu \mathrm{g} / \mathrm{ml}$. c: AS $0.05 \mu \mathrm{g} / \mathrm{ml}$. (40× original magnification). B. Effect of AS on DNA fragmentation of Siha cells - Induction of DNA fragmentation in Siha cells. Treated with AS of different concentration. (lane M, marker; lane 1, $0 \mu \mathrm{g} / \mathrm{ml}$; lane 2, HC $1 \mu \mathrm{g} / \mathrm{ml}$; lane 3, AS $0.025 \mu \mathrm{g} / \mathrm{ml}$; lane 4, AS 0.05 $\mu \mathrm{g} / \mathrm{ml}$; lane 5, AS $0.25 \mu \mathrm{g} / \mathrm{ml}$ ) C: The effect of AS on LDH-activity of Siha cells. LDH-activity was analyzed according to instruction of commercial kit. Each value represents as mean \pm S.D. $(n=3)$. * Significant difference from normal control at $\mathrm{p}<0.05$.

\section{Western blot analysis}

A cell lysate containing $50 \mu \mathrm{g}$ of protein was fractionated by $12 \%$ SDS-PAGE and then proteins were electro-transferred onto nitrophoresis membranes. The membranes were first rinsed with TBST [20 mM Tris-HCl (pH 7.4), 0.15 M NaCl, 0.05\% Tween20] and then blocked with $5 \%(\mathrm{w} / \mathrm{v})$ skim milk in TBST for $1 \mathrm{hr}$ at room temperature. After being washed 3 times for 10 min each in TBST, the blocked membranes were subsequently probed for $24 \mathrm{hrs}$ at $4^{\circ} \mathrm{C}$ with a 1:200 dilution of primary antibodies in blotting buffer. After being washed with TBST for 3 times, the membranes were subsequently incubated for $1 \mathrm{hr}$ at $37^{\circ} \mathrm{C}$ with a $1: 1000$ dilution of HBR-labelled secondary antibodies in blotting buffer. After 3 times wash with TBST, brands of protein on the membrane were visualized with a Western blotting detection kit (Boshide Co, Wuhan, China).

\section{Cell cycle analysis}

Siha cells were incubated with $2.5 \mathrm{mM}$ thymine (cell cycle blocker from G1 to S phase) for $18 \mathrm{~h}$. After centrifugation, cells were resuspended in DMEM medium supplemented with $10 \%$ FBS and cultured for 15 hrs. Cells were treated with $2.5 \mathrm{mM}$ thymine for $15 \mathrm{hrs}$ again, and washed with PBS, then stained with propidium iodide (PI), and analyzed by fluorescence flow cytometry (BectonDickinson, USA). Cells were further treated with different concentrations of acetylshikonin for $24 \mathrm{hrs}$, and then fixed in 75\% methanol and analyzed by fluorescence flow cytometry to determine cell cycle.

\section{Results and Discussion}

\section{Proliferation of cervical cancer cell line Siha and Hela}

Acetylshikonin inhibits the growth of Siha and Hela cells in a time and dose-dependent manner (Fig. 2). The inhibitory effects of acetylshikonin on Siha cells were 
much stronger than that of hydroxycamptothecin, the positive control at the same concentration at $24 \mathrm{~h}$ (Fig. 2a). Furthermore, Siha cells showed significant sensitivity to acetylshikonin even at $24 \mathrm{~h}$ with inhibitory concentrations of $50 \%$ cells (IC50) at $0.84 \mu \mathrm{g} / \mathrm{ml}$ and $0.96 \mu \mathrm{g} / \mathrm{ml}$ respectively. On the other hand, Hela cells showed lower sensitivity to both. Compared to inhibitory effects of acetylshikonin on Siha cells the growth of Hela cells was only significantly inhibited after $48 \mathrm{~h}$ treatment (Fig. 2b). Acetylshikonin showed different inhibitory effects to the two cell lines, indicating that the anti-tumor activity of them had some specificity (Fig. 2c). In this case, the effect of acetylshikonin on cervical cancer Siha cells was analyzed systematically to explore the mechanism of anti-tumor activity and the concentrations of acetylshikonin were determined as $0.025 \mu \mathrm{g} / \mathrm{ml}, 0.05$ $\mu \mathrm{g} / \mathrm{ml}, 0.25 \mu \mathrm{g} / \mathrm{ml}$ in the following experiments.

\section{Apoptosis of cervical cancer cell line Siha}

Siha cells displayed morphological changes, such as condensed, round in shape, invagination of nuclear membrane and formation of blebs, indicating cell death might be caused by apoptosis (Fig. 3A). The genomic DNA from Siha cells was subjected to agarose gel electrophoresis and a typical DNA fragmentation ladder was found, which increased in a dose-dependent manner (Fig. 3B). These results demonstrated that acetylshikonin inhibit Siha cell growth by inducing apoptosis. LDH-activity of acetylshikonin treated Siha cells increased in a dose-dependent manner without significant difference from control group except for cells pretreated with 0.25 $\mu \mathrm{g} / \mathrm{ml}$ acetylshikonin, further confirm that the inhibition on proliferation of Siha cell was apoptosis inducing action (Fig. 3C).

\section{Caspase- 3 and Caspase-8 activities and mRNA expression}

After Siha cells were cultured with medium containing different concentrations of acetylshikonin for $24 \mathrm{hrs}$ respectively, there was a significant increase in the activation of caspase- 3 and caspase- 8 compared with normal control (Fig. 4A). mRNA was extracted from Siha cells treated with acetylshikonin, then it was reverse-transcribed and amplified using caspase- 3 specific primers. The figures of Ct were reduced and amounts of PCR product were significantly increased with the increase in concentrations of acetylshikonin. This result suggested

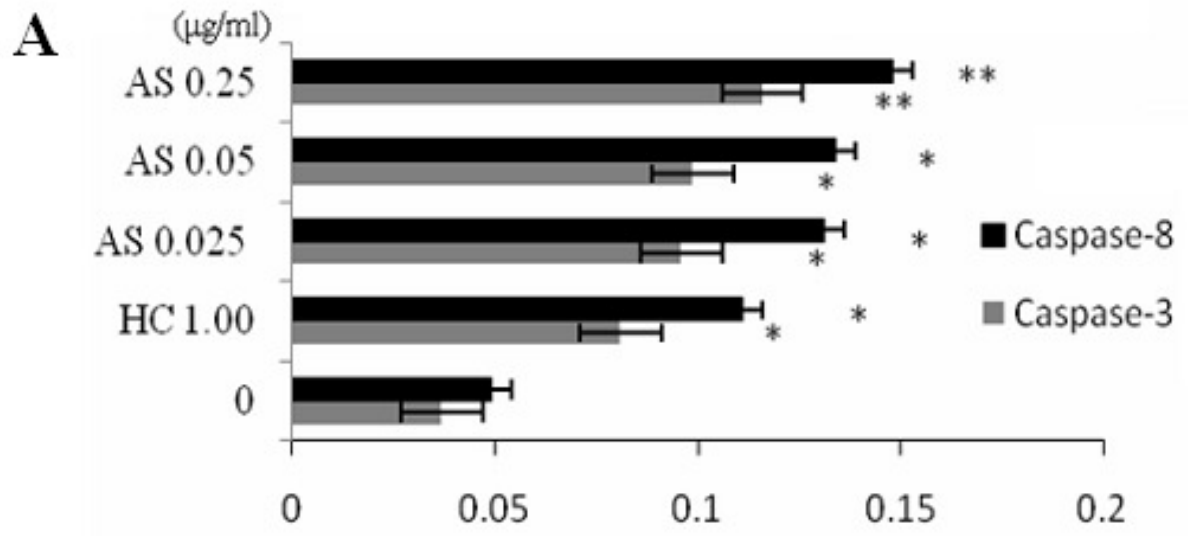

Caspase activity

B

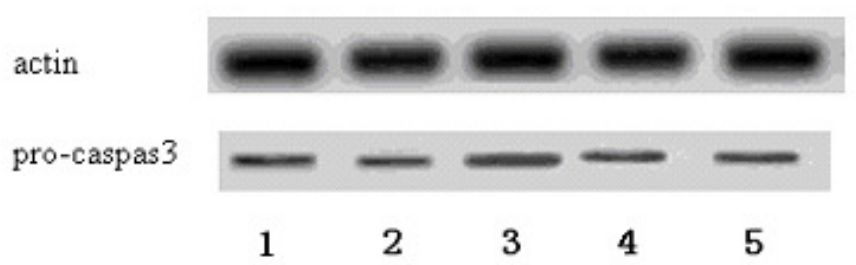

Fig. 4. (A) Effect of AS on Caspase-3 and Caspase-8 activities. Siha cells were cultured with medium containing different concentrations of AS for $24 \mathrm{~h}$ respectively and the activities were analyzed according to instruction of commercial kit Santa

Cruz Biotechnology. Each value represents as mean \pm S.D. $(n=3), *$ Significant difference from normal control at $p<0.05$, **Significant difference from normal control at $\mathrm{p}<0.001$.

(B) Expression level of pro- Caspase-3 proteins in Siha cells. Cells were cultured with medium containing different concentrations of AS for $24 \mathrm{hrs}$ and cell lysates were separated by 12\% SDS-PAGE electrophoresis, then protein bands were detected by Western blot analysis (lane 1: $0 \mu \mathrm{g} / \mathrm{ml}$; lane 2: HC $1 \mu \mathrm{g} / \mathrm{ml}$; lane 3: AS $0.025 \mu \mathrm{g} / \mathrm{ml}$; lane 4 AS $0.05 \mu \mathrm{g} / \mathrm{ml}$; lane 5 AS $0.25 \mu \mathrm{g} / \mathrm{ml})$. 
that acetylshikonin induced apoptosis of Siha cells by activating caspase family proteinases. The expression level of pro- Caspase- 3 proteins was down-regulated in a dose-dependent manner (Fig. 4B), accordingly the expression level of Caspase- 3 was elevated. The result was consistent with the previous findings that acetylshikonin up-regulated Caspase-3 mRNA expression.

\section{Cell cycle arrest in cell line Siha}

After further treatment with different concentrations of acetylshikonin for $24 \mathrm{~h}$, the proportion of cells at $\mathrm{S}$ phase was increased, and the proportion at G2/M was significantly decreased in a dose-dependent manner, indicating cells were blocked at S phase. Acetylshikonin of $0.05 \mu \mathrm{g} / \mathrm{ml}$ and $0.25 \mu \mathrm{g} / \mathrm{ml}$ significantly blocked the transition from $\mathrm{S}$ to $\mathrm{G} 2 / \mathrm{M}$, with ratios of apoptosis at $27.8 \%$, and $52.4 \%$ respectively, suggesting that acetylshikonin inhibited Siha cell growth by arresting Siha cell cycle. It was also found that even acetylshikonin inhibited their activities on Siha cells in a time and dose-dependent manner. Based on system biology thinking, it can be considered that the antitumor efficiency of total naphthoquinones results from multi constituents with multiple mechanisms of action, for complex state of cancer, TCM derived multi combinatorial intervention is new desirable strategy (Alley et al., 1988; Van der Greef et al., 2007; Xiong, Luo, Zhou, Zeng \& Yang, 2009), specially for overcoming drug resistance of chemotherapy.

\section{Conclusion}

In the current study, acetylshikonin is a promising anti-pancreatic cancer therapeutic natural product in the future. MTT assay determined the in vitro anticancer effects of acetylshikonin on human pancreatic cancer Siha cells. Flowcytometry and quantitative RT-PCR were performed to detect the expression level of the associated cell markers and regulatory genes. Acetylshikonin inhibited cell growth in a dose-dependent manner. The preferential expression of Siha cells related marker, regulatory genes were also highlighted. It arrested the cell cycle by blocking transition from $\mathrm{S}$ phase to $\mathrm{G} 2 / \mathrm{M}$ phase and induced apoptosis of Siha through activating caspase-3 and caspase-8. Acetylshikonin can be taken as a promising natural lead for pancreatic cancer.

\section{Acknowledgments}

This work was supported by grants from the Key Program of Natural Science Foundation of State (Grant No. 90709019, $81173500,81373930,81302905,81102556,81202639)$, National Key Technology Research and Development Program of the Ministry of Science and Technology of China (Grant No. 2011BAI03B03, 2011BAI03B06, 2011BAI03B08), National Key Subject of Drug Innovation (Grant No. 2009ZX09502-005), Foundation of Heilongjiang University of Chinese Medicine (Grant no. 201209).

\section{References}

Alley, M. C., Scudiero, D. A., Monks, A., Hursey, M. L., Czerwinski, M. J., Fine, D. L., ... Boyd, M. R. (1988). Feasibility of drug screenig with panels of human tumor cell lines using a microculture tetrazolium assay. Cancer Research, 48, 589-01. PMid:3335022

Chung, H. S., Kang, M., Cho, C., Park, S., Kim, H., Yoon, Y. S., ... Bae, H. (2005). Inhibition of lipopolysaccharide and interferon-gamma-induced expression of inducible nitric oxide synthase and tumor necrosis factor-alpha by Lithospermi radix in mouse peritoneal macrophages. Journal of Ethnopharmacology, 102, 412-7. PMid:16054790. doi:10.1016/j.jep.2005.06.028.

Chung, S. H., \& Lambert, P. F. (2009). Prevention and treatment of cervical cancer in mice using estrogen receptor antagonists. Proceedings of the National Academy of Sciences of the United States of America, 106(46), 19467-72. doi:10.1073/pnas.0911436106. PMid:19901334.

Dzoyem, J. P., Nkuete, A. H., Kuete, V., Tala, M. F., Wabo, H. K., Guru, S. K., ... Tan, N. H. (2012). Cytotoxicity and antimicrobial activity of the methanol extract and compounds from Polygonum limbatum. Planta Medica, 78(8), 787-92. doi:10.1055/s-0031-1298431. PMid:22495442

Fang, X. L., Shao, L., Zhang, H., \& Wang, S. M. (2005). CHMIS-C: A Comprehensive Herbal Medicine Information System for Cancer. Journal of Medicinal Chemistry, 48, 1481-8 doi:10.1021/jm049838d. PMid:15743190

Henares, T. G., Mizutani, F., Sekizawa, R., \& Hisamoto, H. (2008). Single-drop analysis of various proteases in a cancer cell lysate using a capillary-assembled microchip. Analytical and Bioanalytical Chemistry, 391(7), 2507-12. doi:10.1007/s00216-008-2105-x. PMid:18431562

Kelly, J. G., Angelov, P. P., Trevisan, J., Vlachopoulou, A., Paraskevaidis, E., Martin-Hirsch, P. L., \& Martin, F. L. (2010). Robust classification of low-grade cervical cytology following analysis with ATR-FTIR spectroscopy and subsequent application of self-learning classifier eClass. Analytical and Bioanalytical Chemistry, 398(5), 2191-201. doi:10.1007/s00216-010-4179-5. PMid:20857283

Kim, D. H., Jarvis, R. M., Allwood, J. W., Batman, G., Moore, R. E., Marsden-Edwards, E., ... Goodacre, R. (2010). Raman chemical mapping reveals site of action of HIV protease inhibitors in HPV16 E6 expressing cervical carcinoma cells. Analytical and Bioanalytical Chemistr., 398(7-8), 3051-61. doi:10.1007/s00216-010-4283-6. PMid:20957472

Kim, E. K., Kim, E. Y., Moon, P. D., Um, J. Y., Kim, H. M., Lee, H. S., ... Sohn, N. W. (2007). Lithospermi radix extract inhibits histamine release and production of inflammatory cytokine in mast cells. Bioscience, Biotechnology, and Biochemistry, 71, 2886-92. PMid:18071264

Masuda, Y., Nishida, A., Hori, K., Hirabayashi, T., Kajimoto, S., Nakajo, S., ... Nakaya, K. (2003). Beta-hydroxyisovalerylshikonin induces apoptosis in human leukemia cells by inhibiting the activity of a polo-like kinase 1 (PLK1). Oncogene, 22, 1012-23. doi:10.1038/sj.onc.1206200 
Mu, L. H., Wei, N. Y., \& Liu, P. (2012). Cytotoxic triterpenoid saponins from Ardisia gigantifolia. Planta Medica, 78(6), 617-21. doi:10.1055/s-0031-1298254. PMid:22314414

O'Keefe, B. R., Vojdani, F., Buffa, V., Shattock, R. J., Montefiori, D. C., Bakke, J., ... Palmer, K. E. (2009). Scaleable manufacture of HIV-1 entry inhibitor griffithsin and validation of its safety and efficacy as a topical microbicide component. Proceedings of the National Academy of Sciences of the United States of America, 106(15), 6099-104. doi:10.1073/pnas.0901506106. PMCid:PMC2662964

Singh, F., Gao, D., \& Lebwohl, M. G. (2003). Shikonin modulates cell proliferation by inhibiting epidermal growth factor receptor signaling in human epidermoid carcinoma cells. Cancer Letter, 200, 115-21. doi:10.1016/S0304-3835(03)00239-8

Staniforth, V., Wang, S. Y., Shyur, L. F., \& Yang, N. S. (2004). Shikonins, phytocompounds from Lithospermum erythrorhizon, inhibit the transcriptional activation of human tumor necrosis factor alpha promoter in vivo. The Journal of Biological Chemistry, 279, 5877-85. doi:10.1074/jbc.M309185200. PMid:14645256

Takai, N., Ueda, T., Nishida, M., Nasu, K., \& Narahara, H. (2008). Beta-hydroxyisovalerylshikonin has a profound anti-growth activity in human endometrial and ovarian cancer cells. Gynecologic Oncology, 109, 107-14. PMid:18234298. doi:10.1016/j.ygyno.2007.12.020.

Van der Greef, J., Martin, S., Juhasz, P., Adourian, A., Plasterer, T., Verheij, E. R., \& McBurney, R. N. (2007). The art and practice of systems biology in medicine: mapping patterns of relationships. Journal of Proteome Research, 6, 1540-59 doi:10.1021/pr0606530. PMid:17373844

Xiong, W., Luo, G., Zhou, L., Zeng, Y., \& Yang, W. (2009). In vitro and in vivo antitumor effects of acetylshikonin isolated from Arnebia euchroma (Royle) Johnst (Ruanzicao) cell suspension cultures. Chinese Medicine, 4, 14-6. PMid:19594888. doi:10.1186/1749-8546-4-14.

Yue, Q. X., Cao, Z. W., Guan, S. H., Liu, X. H., Tao, L., Wu, W. Y., ... Guo, D. A. (2008). Proteomics characterization of the cytotoxicity mechanism of ganoderic acid D and computer-automated estimation of the possible drug target network. Molecular \& Cellular Proteomics, 7(5), 949-61. doi:10.1074/mcp.M700259-MCP200

Zhang, G. G., Jing, Y., Zhang, H. M., Ma, E. L., Guan, J., Xue, F. N., ... Sun, X. Y. (2012). Isolation and cytotoxic activity of selaginellin derivatives and biflavonoids from Selaginella tamariscina. Planta Medica, 78(4), 390-2. doi:10.1055/s-0031-1298175. PMid:22271084 